\title{
Wajah Politik Perempuan: Studi Etnografi Representasi Suara Perempuan dalam Pemilu Legislatif 2014 di Propinsi Daerah Istimewa Yogyakarta (DIY)
}

\author{
Oleh:
}

\author{
Anis Izdiha 1
}

\begin{abstract}
Abstraksi
Babak baru bagi representasi perempuan dalam politik di Indonesia diakui negara melalui UndangUndang Nomor UU No 8 tahun 2012 tentang Partai Politik yang juga mensyaratkan keterwakilan perempuan $30 \%$ dalam sistem kepartaian. Atas nama keadilan dan meneguhkan identitas perempuan, negara turut campur dalam pemberian hak khusus bagi perempuan untuk berkecimpung di dunia politik atau yang disebut sebagai kebijakan afirmasi. Kajian ini didasari oleh kepentingan untuk melihat kebijakan ini mampu direspon oleh kaum perempuan dalam konteks budaya politik yang dominan dengan mengambil studi kasus representasi suara perempuan dalam Pemilu Legislatif di Propinsi Daerah Istimewa Yogyakarta. Studi dilakukan melalui pendekatan etnografi terhadap 3 calon anggota legislatif, 2 anggota legislatif perempuan, dan 2 tokoh gerakan politik perempuan DIY sejak Maret 2014 hingga Februari 2015. Perspektif perilaku politik dan gender dikembangkan dalam tulisan ini sebagai alat analisis. Hasil temuan studi menunjukkan bahwa perempuan telah berusaha menampakkan wajah baru dalam mencapai tujuan politik mereka. Strategi kolektif kolegial menjadi kekuatan yang dibangun perempuan untuk bergerak atas dasar kesamaan isu kesetaraan gender. Meski demikian, kebijakan ini tak lantas menghilangkan pasung sosial dikarenakan konsruksi patriakhis dan agama dimana perempuan tetap mengalami keterbatasan ruang politik (tidak bebas).
\end{abstract}

Kata kunci : kebijakan afirmasi, representasi politik perempuan, budaya politik patriarkhi.

\begin{abstract}
A new round for women's representation in politics in Indonesia is recognized by the state Act No. 8 of 2012 on Political Parties which also requires the representation of women $30 \%$ in the political party system. In the name of justice and affirming the identity of women, the state intervenes in granting special rights for women to engage in politics which is so-called affirmative policy. This study is aimed at the interest to investigate how the affirmative policy is capable of responding women request in the context of dominant political culture by conducting a case study of women's voice representation in the Legislative Election in Yogyakarta Special Province. The study was conducted through an ethnographic approach to 3 legislative candidates, 2 female legislators, and 2 women political movement leaders from March 2014 to February 2015. The Perspectives on gender and political behavior are developed as an analytical tool in this study. The study finding indicates that women have attempted to reveal a new political face in achieving their political goals. Collective collegial strategy becomes a force deployed as a strategy by that women on the basis of equality of gender equality issues. However, this policy does not necessarily eliminate social obstacles due to patriarchal and religious constructs where women still experience a limited political space (unfree).
\end{abstract}

Keywords: affirmative policy, women's political representation, patriarchal political culture

\footnotetext{
${ }^{1}$ Anis Izdiha menyelesaikan studi sarjana Antropologi pada Fakultas Ilmu Budaya (FIB), UGM. Studi ini merupakan rangkuman dari skripsi yang pernah dikerjakannya pada tahun 2016.
} 
Jurnal Pemikiran Sosiologi Volume 4 No. 2, 2017

Wajah Politik Perempuan: Studi Etnografi Representasi Suara Perempuan dalam Pemilu Legislatif 2014 di Propinsi Daerah Istimewa Yogyakarta (DIY)

Anis Izdiha

\section{A. Pengantar}

Perempuan dan politik merupakan konsep yang mempertemukan antara sekelompok orang berjenis kelamin perempuan dan negara. Ruang politik merupakan bagian tak terpisahkan dari serangkaian kepentingan negara dalam menaungi berbagai kepentingan rakyatnya. Ruang politik terbuka diwujudkan melalui agenda negara yang bernama Pemilihan Umum atau yang sering disebut Pemilu. Kebijakan pengarusutamaan gender Indonesia di bidang politik terdengar pada sidang Paripurna DPR RI tanggal 18 Februari 2003 yang membolehkan adanya kuota minimal $30 \%$ bagi setiap partai untuk merekrut perempuan sebagai calon wakil rakyat yang dituliskan dalam pasal 65 ayat 1 UU No. 12 tahun 2003. Regulasi formal terus bergulir hingga hadirnya UU No 22 tahun 2007 tentang penyelenggaraan pemilu dan UU No. 2 tahun 2008 tentang partai politik yang diantaranya memuat keterwakilan perempuan sebanyak $30 \%$ pada partai kemudian disempurnakan dengan UU No. 8 tahun 2012 tentang pemilu legislatif. Ada 9 pasal yang mengatur keterwakilan perempuan di dalam partai politik. Partai politik merupakan sebuah organisasi untuk memperjuangkan nilai atau ideologi tertentu melalui penguasaan struktur kekuasaan dan kekuasaan itu diperoleh melalui keikutsertaannya di dalam pemilihan umum (Pamungkas, 2011).

Kebijakan affirmative pemenuhan kuota mininal $30 \%$ dalam pencalonan legislatif pun 'memaksa' setiap elemen masyarakat baik laki-laki dan perempuan untuk mampu menerima bahwa perempuan pun didorong untuk berpolitik. Pihak yang amat bersentuhan langsung adalah partai politik peserta Pemilu. Kebijakan ini menyebabkan adanya perubahan orientasi visi dan misi partai. Nuansa perempuan mulai hadir dalam konsentrasi garapan partai. Perubahan orientasi sasaran/ideologi parpol ini dapat kita lihat dalam buku "Partai-Partai Politik Indonesia" yang diterbitkan oleh Kompas 2004, dari 24 partai politik peserta pemilu 2004 yang mengajukan diri ke Komisi Pemilihan Umum (KPU) semuanya mulai menyebutkan perempuan sebagai sasaran program. Misalkan saja Partai PDK (Partai Persatuan Demokrasi Kebangsaan) yang menyebutkan perempuan sebagai kelompok strategis di Indonesia yang wajib untuk diperhatikan. Partai Perhimpunan Indonesia Baru menyebutkan adanya kalimat 'perempuan yang merdeka' sebagai salah satu basis perjuangan mereka. Begitu pula dengan partaipartai besar lainnya seperti Partai Amanat Nasional (PAN), Partai Kebangkitan Bangsa (PKB), Partai Kesejahteraan Sosial (PKS), Partai Demokrat, dan Partai Demokrasi Indonesia-Perjuangan(PDI-P) (Klingeman, 2000).

Perilaku politik dapat dikatakan sebagai kegiatan yang berkenaan dengan proses pembuatan dan pelaksanaan keputusan politik. Faktor-faktor yang mempengaruhi perilaku politik aktor politik ada empat (Subakti, 2007) , yakni:

(1) lingkungan sosial politik tak langsung, seperti sistem politik, sistem ekonomi, sistem budaya dan media massa;

(2) lingkungan sosial politik langsung seperti keluarga, agama, sekolah dan kelompok pergaulan; 
Jurnal Pemikiran Sosiologi Volume 4 No. 2, 2017

Wajah Politik Perempuan: Studi Etnografi Representasi Suara Perempuan dalam Pemilu Legislatif 2014 di Propinsi Daerah Istimewa Yogyakarta (DIY)

Anis Izdiha

(3) struktur kepribadian yang tercermin dalam sikap individu yang didasari oleh kepentingan, penyesuaian diri, dan pertahanan diri;

(4) faktor sosial politik langsung yang berupa situasi, yakni keaadaan yang mempengaruhi aktor secara langsung ketika akan melakukan suatu kegiatan seperti cuaca, keadaan keluarga, ancaman, suasana kelompok, dan seterusnya.

Menurut Koentjaraningrat (2009), perilaku merupakan satu dari tiga wujud kebudayaan. Perilaku para perempuan politik pun menjadi salah satu aspek di dalam melihat budaya politik berkembang di kalangan politisi perempuan. Almond dan Verba (Sastroatmodjo, 1995) mengartikan kebudayaan politik suatu bangsa sebagai distribusi pola-pola orientasi khusus menuju tujuan politik diantara masyarakat bangsa. Budaya politik menggerakkan pemahaman pada perpaduan antara dua tingkat orientasi politik, yaitu sistem dan individu(Syamsyudin, 1991). Almond dan Verba lebih lanjut menjelaskan bahwa dari polapola orientasi khusus tersebut dapat dipakai apabila telah dipahami berbagai cara yang sistematis orientasi individu terhadap objek politik yang ia pahami. Terdapat tiga komponen dalam objek politik yaitu komponen kognitif, yaitu yang menyangkut pengetahuan tentang politik dan kepercayaan pada politik, peranan, dan segala kewajibannya. Komponen kedua adalah orientasi afektif yakni perasaan terhadap sistem politik, perananannya, para aktor, dan penampilannya. Komponen ketiga adalah orientasi evaluatif yakni keputusan dan praduga tentang objek-objek politik yang secara tipikal melibatkan kombinasi standar nilai dan kriteria dengan informasi dan perasaan
(Sastroatmodjo, 1995:36). Penjelasan di atas menjadi landasan utama di dalam studi tentang fenomena "politik perempuan" ini yang tak lain adalah bagaimana politik dimaknai sebagai sebuah orientasi dari ekspresi politik yang didapat melalui pengalaman, tidak dalam bentuk bagaimana politik dimaknai sebagaimana digunakan sebagai alat mencapai kekuasaan, tapi bagaimana politik sebenarnya dihayati oleh perempuan. Sejalan dengan fenomena yang terjadi, Wolf (1997) mengatakan perempuan-perempuan pada abad 21 mulai "melek kuasa". Para kaum wanita mulai bergerak menuju kesadaran akan kebutuhan memperoleh kekuasaan karena di sana dia bisa melakukan kontrol. Perempuan menurut Wolf memiliki semacam khayalan tentang "penyelamatan" hak-hak mereka dalam cara pikir yang feminis, dalam lamunan, yang telah diajarkan sejak kecil untuk dipakai memikirkan kehendaknya sendiri. Khayalan itu berbunyi: suatu hari nanti, saat kita entah bagaimana dibuat setara dengan laki-lakiakibat perubahan zaman, berkat keputusan pemerintah, atau apapun juga- maka kita akan menerima apa yang kita butuhkan.

Politik menjadi sebuah 'khayalan' bagi perempuan sebagai upaya dalam proses mewujudkan berbagai 'kebutuhan' perempuan yang belum ia dapatkan. Politik dipandang sebagai sebuah jalan untuk meminta hak-hak perempuan. Ratih (2009) mengatakan semangat revolusioner yang mewarnai gerakan perempuan sejak dekade ke-2 abad ke-20 mendorong perempuan untuk menentang nilai-nilai Victorian dan tradisi feodal priyayi: "perempoean dipandang seperti perhiasan roemah tangga dan mendjadi kepalanja koki...memilih doedoek diam 
Jurnal Pemikiran Sosiologi Volume 4 No. 2, 2017

Wajah Politik Perempuan: Studi Etnografi Representasi Suara Perempuan dalam Pemilu Legislatif 2014 di Propinsi Daerah Istimewa Yogyakarta (DIY)

Anis Izdiha

sambil makan angin". Penjelasan di atas juga menuntun pada bahasan studi ini dimana perilaku politik perempuan menjadi gerakan perempuan melawan 'tradisi' dan stigma yang melekat padanya. Seperti disebutkan diatas, gerakan politik perempuan berusaha untuk 'melawan' ideologi patriarkhi yang selama ini telah terkonstruksi dengan baik di dalam masyarakat khususnya DIY.

\section{B. Metode dan Kerangka Teoritik}

Daerah Istimewa Yogyakarta menjadi wilayah yang menarik untuk diteliti, keterlibatan perempuan terus naik dari 2004 sejumlah 5\% naik menjadi 9\% di Pemilu 2009 (Data KPU, 2014). Terjadi peningkatan meskipun kuota minimal 30\% belum terpenuhi. DIY dalam data Puskapol UI(2013) termasuk dalam 9 besar DPRD Provinsi dengan Keterpilihan Perempuan Kategori Tinggi (>20 \%). Begitu pula pada Pemilu 2014, pada saat pencalonan seluruh partai politik telah menerapkan kuota 30\% bahkan beberapa partai merekrut calon legislatif perempuan lebih dari $30 \%$. Sebuah prestasi dan juga pertanyaan menarik tentang bagaimana keterlibatan perempuan ini mengalami peningkatan. Daerah Istimewa Yogyakarta sebagai satu wilayah yang memiliki struktur pemerintahan sebagai 'daerah khusus' karena Gubernur sebagai posisi tertinggi di sebuah provinsi diduduki oleh seorang Sultan dan harus berjenis kelamin laki-laki pun menarik dalam kaitannya dengan konsep kepemimpinan politik yang ada di DIY.

Cakupan informan adalah lima orang yang terdiri dari calon legislatif maupun anggota legislatif yang tergabung dalam Forum Komunikasi Perempuan
Politik DIY dan NARASITA serta dua orang aktivis perempuan yang mengawa jalannya urutan caleh tidak bisa langsung.. Pertimbangan pemilihan informan penulis dasarkan pada pembedaan kelas ekonomi, status hubungan keluarga (relasi suami isteri di dalam keluarga) status pendidikan dan pengalaman berbeda dalam kegiatan politik pemilu 2014, yakni informan dengan pengalaman satu kali nyaleg namun gagal, dua kali nyaleg namun gagal, satu kali nyaleg berhasil, caleg incumbent namun gagal, dan caleg incumbent yang berhasil.

Dalam melakukan penelitian ini, data etnografi diperoleh melalui metode observasi partisipatoris, wawancara, dan dokumentasi. Observasi ini lebih khusus bersifat partisipatoris atau participant observation. (Ahimsa-Putra, 2007) dengan pendekatan kepada informan dan juga terhadap komunitas tersebut secara langsung dalam berbagai kegiatan yang dilakoni informan. Berawal dari menjadi volunter, peneliti melakukan observasi pada Maret-Mei 2014 di organisasi NARASITA dan anggotanya. Metode wawancara dilakukan dengan pendekatan-pendekatan antara lain melakukan sapaan, terbuka tidak ada tujuan eksplisit, menghindari pengulangan dan dominasi dalam pembicaraan (Spradley, 1997). Studi ini membutuhkan banyak ruang pribadi karena berkaitan dengan pendalaman sisi historis kehidupan informan. Pengalaman menjadi hal penting yang ingin peneliti gali disamping bagaimana informan melakukan interaksi terhadap lingkungan sosial dan lingkungan politiknya. Studi dokumen digunakan mengumpulkan data melalui dokumen file-file tertulis seperti buku, artikel, koran, novel, data catatan harian (diary), biografi, 
Jurnal Pemikiran Sosiologi Volume 4 No. 2, 2017

Wajah Politik Perempuan: Studi Etnografi Representasi Suara Perempuan dalam Pemilu Legislatif 2014 di Propinsi Daerah Istimewa Yogyakarta (DIY)

Anis Izdiha

autobiografi, data-data statistik dan seterusnya dilakukan ketika akan melakukan penelitian dan setelah melakukan penelitian (Davies, 1998). Berbagai referensi baik berupa surat kabar, artikel, life history, lokakarya, dan lain sebagainya terkait perempuan politik menjadi sumber data dalam studi ini.

Kerangka teoritis yang dikembangkan dalam analisis berpijak pada konsep mengenai patriarkhi. Patriakhi (Saptari,1997) adalah sebuah sistem yang diatur oleh laki-laki yang kekuasaannya dijalankan melalui institusi sosial, politik, ekonomi, dan agama. Sistem ini bersifat hierarkis, agresif, dan muncul secara independen dari perubahan-perubahan sosial seperti sistem kapitalisme yang membagi sektor domestik dan sektor publik. Sistem ini memungkinkan laki-laki menjadi lebih dominan dibanding dengan perempuan di sektor publik (Gamble, 2010).

Di sisi lain, konsep kekuasaan dalam budaya Jawa masih mempercayai bentuk kepemimpinan politik "paternalistik" cocok dengan karakteristik budaya Jawa. Pengertian kekuasaan dalam paham Jawa menekankan upaya untuk menyatukan hal-hal yang bertolak belakang, penggambaran klasiknya adalah kombinasi laki-laki dan perempuan. Namun demikian bukan penyatuannya yang ditekankan namun lebih kepada menyandingkan bentuk dan karakteristik feminis-maskulin, dalam hal ini prinsip keseimbangan yang bekerja dalam konsistensi dengan nilai keselarasan (Handayani, 2004). Konsep kekuasaan Jawa ini kental dengan spesifikasi pembagian kerja antara laki-laki dan perempuan sebagai bagian untuk menuju keseimbangan. Hubungan kekuasaan ada pada hubungan fungsional peran laki-laki dan perempuan yang dilembagakan.

Sebagaimana politik dipresepsikan oleh perempuan sebagai bagian pemenuhan kebutuhan diri, bayangan akan hadirnya negara yang sensitif terhadap perempuan menjadi tujuan penting dalam agenda politik perempuan. Pengambilan keputusan negara haruslah melihat bagaimana perempuan serta persoalan domestik yang selama ini digelutinya sebagai bahan ajar pengambilan keputusan. Politik menurut perempuan dikenal dengan ungkapan the personal is political (yang pribadi adalah politik) Istilah ini pertama kali dimunculkan oleh Carol Hanisch, seorang penggiat feminisme Amerika, dalam sebuah tulisan "Notes from the second year" di tahun 2007 (Perdana, 2013). Aktivitas politik sangat lekat dengan kata perempuan karena perempuan telah terbiasa mengambil keputusan dalam kehidupan seharisehari mulai dari hal kecil seperti mengatur makan dan minum hingga persoalan sulit seperti mempertimbangkan keuangan (Adelina, 2008).

Cantor dan Bernay (1992) menulis mengenai kiprah wanita Amerika di dalam dunia politik yang mengalami hambatan sosial dan politik regulasi. Nikki Craske (1999) melakukan penelitian pada perempuan politik yang ada di Amerika Latin. Craske memberikan konsep baru yakni 'political Motherhood' atau politik perempuan yang memberikan gambaran mengenai bagaimana perempuan diberikan kesempatan yang luas untuk berpartisipasi aktif dalam berbagai sektor seperti tenaga kerja, politik, maupun berpartisipasi dalam gerakan sosial. Utami (2001) melakukan studi tentang perempuan politik di parlemen menemukan 
Jurnal Pemikiran Sosiologi Volume 4 No. 2, 2017

Wajah Politik Perempuan: Studi Etnografi Representasi Suara Perempuan dalam Pemilu Legislatif 2014 di Propinsi Daerah Istimewa Yogyakarta (DIY)

Anis Izdiha

adanya diskriminasi dalam hak angket dan kompromi politik oleh sebab budaya yang berkembang adalah perempuan sebagai "Konco Wingking" yang hanya mendukung dari belakang panggung politik saja.

\section{Urgensi Kuota 30 \% dan Praktik Representasi Perempuan dalam Politik di Indonesia}

\section{Pada tahun 1995 diadakanlah Konferensi}

Perempuan Dunia di Program Aksi Beijing dengan fokus program "Perempuan dalam Kekuasaan dan Pembuatan Keputusan (Women in Power and Decision Making). UNDP (2013) menuliskan beberapa rekomendasi penting dari program itu sebagai berikut:

1) Membuat agenda yang jelas untuk mengakhiri semua perilaku diskriminasi hukum terhadap perempuan (menurut paduan CEDAW), serta membangun kerangka kerja untuk memajukan kesetaraan hukum

2) Memulai langkah-langkah khusus yang dalam jangka pendek ditujukan untuk mencapai posisi $30 \%$ dalam kedudukan pembuat keputusan di tingkat nasional dan $50 \%$ dalam jangka panjang

3) Memobilisasi upaya nasional dan internasional untuk memfasilitasi akses yang besar -bagi perempuan khususnya- terhadap kesempatan dalam politik dan ekonomi.

Berdasarkan sejarah itulah kemudian dicapai angka $30 \%$ sebagai strategi jangka pendek untuk keterwakilan perempuan di dalam lembaga pembuat kebijakan. Tujuannya adalah untuk menjamin kesetaraan akses bagi partisipasi aktif perempuan dalam struktur kekuasaan dan pembuatan keputusan serta meningkatkan kapasitas perempuan untuk berpartisipasi dalam pembuatan keputusan dan kepemimpinan. Rekomendasi ini kemudian berdampak pada Indonesia. Pemilihan umum tahun 2004 menjadi kali pertama perhatian terhadap hadirnya politisi perempuan yang diwujudkan dalam pasal 65 undang-undang Pemilu 2004 yang menyatakan bahwa partai politik 'boleh' mengajak perempuan untuk masuk ke dalam fraksi mereka.

Hingga pada tahun 2008, muncul wacana mengenai perlunya kebijakan affirmative action bagi perempuan. Kebijakan ini merupakan terobosan bagi partisipasi aktif perempuan; sudah saatnya memaksa partai politik untuk lebih memperhatikan kaderisasi perempuan;tindakan afirmatif ini harus dilakukan untuk mendorong perempuan masuk dalam partai politik. Oleh karenanya diperlukan strategi di dalam mengawal hadirnya kebijakan ini. Strategi tersebut dirancang dalam tiga tahapan. Berikut penjelasannya dijabarkan dalam bagan 'Langkah Strategi Advokasi Desain Kebijakan Affirmative dalam Undang-Undang Politik'.

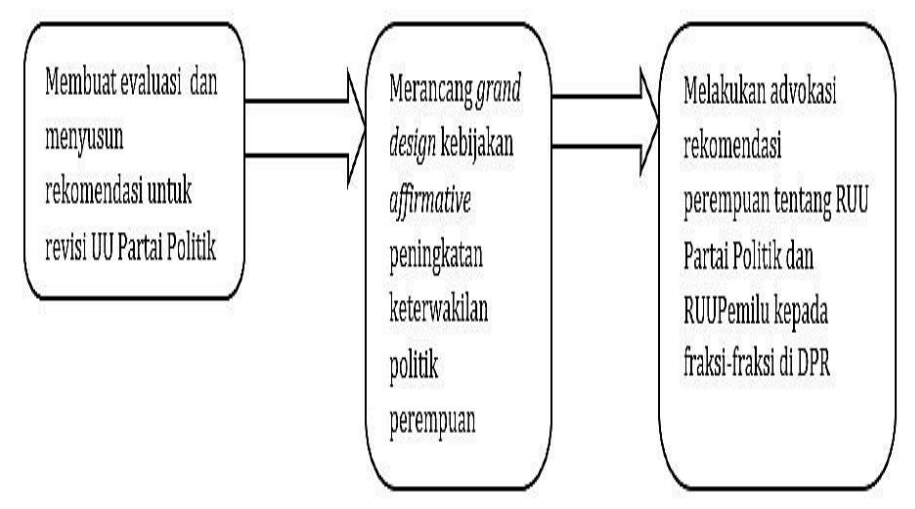

Gambar 01. Bagan Langkah Stategi Advokasi Desain Kebijakan Affirmative dalam UU (Sumber: UNDP, 2013) 
Jurnal Pemikiran Sosiologi Volume 4 No. 2, 2017

Wajah Politik Perempuan: Studi Etnografi Representasi Suara Perempuan dalam Pemilu Legislatif 2014 di Propinsi Daerah Istimewa Yogyakarta (DIY)

Anis Izdiha

Tahun 2008, kumandang seruan untuk terus maju berpolitik kian terdengar oleh para perempuan negeri Indonesia ini. Pengakuan atas tindakan politik perempuan diakui bahkan dilegitimasikan melalui Undang-Undang No. 2 tahun 2008 yang disempurnakan melalui Undang-Undang No. 8 tahun 2012 tentang keterwakilan perempuan di dalam perempuan di dalam Pemilu Legislatif.

Kebijakan kuota $30 \%$ merupakan kebijakan yang lahir pada tingkat nasional. Tentu saja akan kita jumpai respon yang berbeda pada tiap wilayah di Indonesia. DIY sebagai bagian dari satu wilayah di Indonesia dengan konsep kepemimpinan seperti yang sudah dipaparkan pada pembahasan sebelumnya menjadi menarik untuk dilihat pada tataran implementasi kebijakan. Respon ini kemudian akan kita lihat dalam dinamika gerakan perempuan di DIY serta perputaran hasil pemilu di DIY pada pemilu 2004, pemilu 2009, dan pemilu 2014 karena tiga periode pemilu ini menjadi periode implementasi kebijakan kuota 30\%.

Kemenangan DIY pada 2009 disebut-sebut sebagai pencapaian tertinggi dalam dasawarsa terakhir pada Pemilu. Daerah Istimewa Yogyakarta mengalami kenaikan signifikan keterwakilan perempuan di dalam politik. DIY menjadi satu dari 9 wilayah di Indonesia yang menduduki peringkat ke8 adanya kenaikan keterwakilan perempuan di badan legislatif. Kenaikan di DIY dapat dikatakan menjadi kenaikan tinggi dengan tingkat kenaikan lebih dari 100\%, di tahun 2004 tingkat keterwakilan hanya $9 \%$ dan pada 2009 tingkat kenaikan menjadi $20 \%$. Prestasi yang patut kita apresiasi bersama mengenai jerih payah para anggota legislatif perempuan dalam upaya Pemilu 2009.

\begin{tabular}{|l|l|l|l|l|l|}
\hline No & Provinsi & $\begin{array}{l}\text { Jumlah } \\
\text { Perempuan }\end{array}$ & $\begin{array}{l}\text { \% Pemilu } \\
2004\end{array}$ & $\begin{array}{l}\text { \% Pemilu } \\
2009\end{array}$ & Perubahan \\
\hline 1 & Maluku & 45 & $4 \%$ & $31,11 \%$ & Naik \\
\hline 2 & Lawa Barat & 100 & $9 \%$ & $25 \%$ & Naik \\
\hline 3 & DKI Jakarta & 94 & $14 \%$ & $24,47 \%$ & Naik \\
\hline 4 & Sulawesi Utara & 45 & $17 \%$ & $22,22 \%$ & Naik \\
\hline 5 & Lawa Tengah & 100 & $15 \%$ & $21 \%$ & Naik \\
\hline 6 & $\begin{array}{l}\text { Kalimantan } \\
\text { Timur }\end{array}$ & 53 & $15 \%$ & $20,75 \%$ & Naik \\
\hline 7 & Sumatra Utara & 100 & $6 \%$ & $20 \%$ & Naik \\
\hline 8 & Yogyakarta & 55 & $9 \%$ & $20 \%$ & Naik \\
\hline 9 & Gorontalo & 45 & $14 \%$ & $20 \%$ & Naik \\
\hline
\end{tabular}

Tabel 01. DPRD Provinsi dengan Keterpilihan Perempuan Kategori Tinggi ( $>20 \%$ ) Hasil Pemilu 2009 (Sumber : Puskapol UI , 2010)

Prestasi tersebut diatas menimbulkan berbagai pertanyaan mengenai bagaimana strategi pemenangan perempuan di dalam pemilu 2009 atau peristiwa macam apa yang dapat mendorong meningkatkan keterwakilan perempuan di dalam politik. Ada beberapa faktor tentu saja, Pada putaran pemilu 2009 kebijakan affirmative action telah dilaksanakan serta diperkuat dengan UU No 2 tahun 2008 tentang partai politik mengenai jumlah minimal 30\% perempuan dalam kepengurusan, UU No 10 tahun 2008 juga memuat penempatan $30 \%$ perempuan dalam daftar calon, penempatan caleg perempuan juga diatur dengan ketentuan dalam tiga nama calon legislatif terdapat satu nama perempuan. Meskipun belum semua partai mengikuti amanah kebijakan ini dengan sepenuh hati akan tetapi praktis ada peluang penjaringan perempuan yang lebih tinggi dibanding tahun 2004. 
Jurnal Pemikiran Sosiologi Volume 4 No. 2, 2017

Wajah Politik Perempuan: Studi Etnografi Representasi Suara Perempuan dalam Pemilu Legislatif 2014 di Propinsi Daerah Istimewa Yogyakarta (DIY)

Anis Izdiha

Perempuan merayakan kebijakan kuota 30\% dengan 'suka cita' dan penuh gembira. Capaian di atas menjadi gambaran keberhasilan kedua bagi perjuangan politik perempuan. Kebijakan kuota $30 \%$ terbukti sukses dalam meloloskan perempuan tidak hanya pada tataran masuk ke dunia politik namun juga menjadi 'wakil' rakyat. Impian akan peran 'memimpin' serta terlibat dalam 'membuat keputusan khalayak banyak' semakin terbuka lebar di hadapan mata. Kebijakan kuota 30 '\% tanpa sanksi bagi partai politik di tahun 2009 kemudian kembali didesakkan untuk menjadi aturan 'wajib' bagi parpol untuk maju ke arena pemilu.

Pada Pemilu 2014, peraturan Undang-Undang Pemilu sudah 'mewajibkan' bagi setiap partai politik yang akan maju untuk mengisi penuh perekrutan dan pencalonan perempuan sebanyak $30 \%$ di masing-masing daerah pemilihan. Akan tetapi peraturan ini tidak menunjukkan signifikasi terhadap hasil capaian pada tahun 2014, Daerah Istimewa Yogyakarta mengalami penurunan, untuk DPRD Provinsi (DIY) turun hampir 50 \%, dari 12 orang menjadi 6 orang. DPRD Bantul juga mengalami penurunan dari 7 orang menjadi 3 orang. Keterwakilan perempuan di DPRD Kota Yogyakarta dan DPRD Kabupaten Sleman meningkat, di DPRD Kota dari 5 orang menjadi 10 orang, meningkat 100 $\%$ sehingga dari total jumlah anggota legislatif di Kota, keterwakilan mencapai 25 \%. DPRD Sleman meningkat dari 9 orang menjadi 13 orang dengan keterwakilan mencapai 26\%. Sementara pada DPRD Kulon Progro dari 5 orang menjadi 7 orang atau sekitar 15,55 \% dan DPRD Gunungkidul naik dari 6 orang menjadi 7 orang atau sekitar $15.55 \%$.

\begin{tabular}{|l|l|l|l|}
\hline \multirow{2}{*}{ Lembaga } & \multicolumn{3}{|c|}{ Keterwakilan Hasil Pemilu Legislatif DPRD DIY 2014 } \\
\cline { 2 - 4 } & Perempuan & Laki-Laki & \% Perempuan \\
\hline DPRD Provinsi & 6 & 39 & $10,91 \%$ \\
\hline DPRD Kota & 10 & 30 & $25,00 \%$ \\
\hline DPRD Sleman & 13 & 37 & $26,00 \%$ \\
\hline DPRD Bantul & 3 & 42 & $6,67 \%$ \\
\hline $\begin{array}{l}\text { DPRD Gunung } \\
\text { Kidul }\end{array}$ & 7 & 38 & $15,55 \%$ \\
\hline $\begin{array}{l}\text { DPRD Kulon } \\
\text { Progo }\end{array}$ & 7 & 33 & $17,5 \%$ \\
\hline Jumlah & 46 & 219 & $17,35 \%$ \\
\hline
\end{tabular}

Tabel 02. Hasil Pemenangan Perempuan Politik Pemilu 2014 (Sumber : NARASITA, 2014)

Data di atas memberikan kita gambaran bahwa keterwakilan perempuan belum terwujud 30\% pada Pemilu 2014 bahkan terjadi penurunan di beberapa wilayah. Keterwakilan perempuan pada periode pemilu 2014 hanya 17,35 \%. Persoalan lain yang muncul pada Pemilu 2014 adalah diberlakukannya UU Pemilu baru yakni UU No 8 tahun 2012 dimana para calon legislatif baik dari partai politik yang sama maupun berbeda memiliki kesempatan untuk dipilih langsung oleh masyarakat.

\section{Wajah Politik Perempuan: Realitas dan Budaya Politik dalam Temuan Studi Etnografi di Yogyakarta}

Di dalam penelitian ini, perempuan politik adalah mereka yang akan mengikuti proses pencalonan legislatif. Proses pencalonan dimulai dari proses masuk ke dunia partai, mengikuti proses pemilu, dan jika terpilih maka dirinya akan duduk di kursi parlemen (legislatif) di DIY. Perempuan politik hadir dari kalangan masyarakat luas yang kemudian mencalonkan diri menjadi anggota legislatif melalui jalur partai. Tulisan ini memfokuskan diri pada lima 
Jurnal Pemikiran Sosiologi Volume 4 No. 2, 2017

Wajah Politik Perempuan: Studi Etnografi Representasi Suara Perempuan dalam Pemilu Legislatif 2014 di Propinsi Daerah Istimewa Yogyakarta (DIY)

Anis Izdiha

\begin{tabular}{|c|c|c|c|c|c|c|c|c|c|}
\hline Inisial & Status & Umur & $\begin{array}{l}\text { Pendidi } \\
\text { kan }\end{array}$ & $\begin{array}{l}\text { Pekerjaan } \\
\text { Asal }\end{array}$ & $\begin{array}{l}\text { Dana } \\
\text { Kampanye }\end{array}$ & Keterangan & Agama & Partai & Etnis \\
\hline An & Cerai & $\begin{array}{l}35 \\
\text { tahun }\end{array}$ & SMA & $\begin{array}{l}\text { Ibu Rumah } \\
\text { Tangga } \\
\text { (DPRD } \\
\text { Periode 2009- } \\
\text { 2014) }\end{array}$ & 200 an juta & $\begin{array}{l}\text { Incumbent, } \\
\text { Terpilih } \\
\text { Pemilu } 2014\end{array}$ & Katolik & Gerindra & $\begin{array}{l}\text { Lahir di } \\
\text { Palu, } \\
\text { Suku } \\
\text { Jawa }\end{array}$ \\
\hline Ar & Kawin & $\begin{array}{l}50 \\
\text { tahun }\end{array}$ & $\begin{array}{l}\text { S1 } \\
\text { [Akutan } \\
\text { si) }\end{array}$ & Penguasaha & 200an juta & $\begin{array}{l}\text { Dua kali } \\
\text { nyaleg, Tidak } \\
\text { terpilih pada } \\
\text { Pemilu } 2014\end{array}$ & Islam & PAN & Jawa \\
\hline Nv & Kawin & $\begin{array}{l}35 \\
\text { tahun }\end{array}$ & $\begin{array}{l}\text { S2 (Ilmu } \\
\text { Politik } \\
\text { Pemerin } \\
\text { tahan) }\end{array}$ & Pekerja Sosial & $\begin{array}{l}\text { Kurang } \\
\text { dari } 100 \\
\text { juta, }\end{array}$ & $\begin{array}{l}\text { Satu kali } \\
\text { nyaleg, Tidak } \\
\text { Terpilih }\end{array}$ & Islam & Golkar & Jawa \\
\hline $\mathrm{Rb}$ & Kawin & $\begin{array}{l}49 \\
\text { tahun }\end{array}$ & $\begin{array}{l}\text { D3 } \\
\text { [Hukum }\end{array}$ & $\begin{array}{l}\text { Ibu Rumah } \\
\text { Tangga }\end{array}$ & $\begin{array}{l}\text { Kampanye } \\
\text { tandem, } \\
100 \text { an juta }\end{array}$ & $\begin{array}{l}\text { Dua kali } \\
\text { nyaleg, } \\
\text { Terpilih pada } \\
\text { Pemilu } 2014\end{array}$ & Islam & Gerindra & $\begin{array}{l}\text { Lahir di } \\
\text { Lampung, } \\
\text { Suku } \\
\text { Jawa }\end{array}$ \\
\hline Ft & Kawin & $\begin{array}{l}50 \\
\text { tahun }\end{array}$ & $\begin{array}{l}\text { S1 } \\
\text { [Hukum }\end{array}$ & Pengacara & 200an juta & $\begin{array}{l}\text { Terpilih pada } \\
\text { Pemilu 1997- } \\
2009 \text {, Tidak } \\
\text { terpilih } \\
\text { Pemilu } 2014\end{array}$ & Islam & Golkar & Jawa \\
\hline
\end{tabular}

Tabel 03. Deskripsi Informan: 5 Perempuan Politik (Sumber: Diolah dari data primer)

calon anggota legislatif yang dua diantaranya terpilih dan duduk di kursi parlemen periode Pemilu 2014. Latar belakang kehidupan sebelum menjadi seorang caleg maupun anggota legislatif(aleg) menjadi fokus penjelasan pada sub bab ini. Lima orang ini yang kemudian saya sebut dengan inisial agar mampu memberikan pandangan jelas dari siapa yang diceritakan tanpa mengganggu privasi dari sang informan.

Lima orang dari informan ini memiliki latar belakang yang berbeda dengan minat yang berbeda pula. Dalam hal usia, perempuan politik ada pada tataran usia produktif dengan interval umur 35-52 tahun. Agama yang dianut pun beragam, informan dari penelitian ini terdiri dari seorang yang beragama Katolik dan Islam namun penganut agama Islam tetap menjadi yang dominan. Status hubungan di dalam keluarga hampir semuanya adalah mereka yang telah menikah dan memiliki suami. Status kawin ini menjadi citra dari posisi diri dengan kematangan dan kemandirian dari seorang perempuan yang telah berkeluarga.

Latar belakang yang berbeda juga telah membuat pengalaman berbeda atas pembelajaraan hidup yang ada. Nv mulai tertarik ke dunia politik oleh sebab pengalaman tidak enak yang ia terima sebagai bentuk ketidakadilan hukum, sebagaimana dituturkannya:

"Saya tertarik ke dunia politik karena memiliki anak difabel kemudian saat saya mendaftarkan diri ke SLB Giwangan dan mendapat sedikit diskriminasi karena tidak diterima, saya merasa negara absen di dalam memenuhi kebutuhan para disabilitas".

Pengalaman pribadi akan lebih kuat mengakar dalam diri seseorang karena berkaitan langsung dengan pemilik pengalaman. Pengalaman pribadi juga menjadi acuan emosi serta pijakan pikir bagi banyak politisi yang terjun ke dunia politik. Pengalaman pikir ini kemudian dihayati dalam benak mereka sebagai sesuatu yang mesti diperjuangkan. Penghayatan kemudian diproduksi 
Jurnal Pemikiran Sosiologi Volume 4 No. 2, 2017

Wajah Politik Perempuan: Studi Etnografi Representasi Suara Perempuan dalam Pemilu Legislatif 2014 di Propinsi Daerah Istimewa Yogyakarta (DIY)

Anis Izdiha

sebagai basis data dalam setiap logika pikir bagi pelaku politik untuk bersikap dan menentukan arah perjuangan yang akan diusung oleh seorang perempuan politik.

Ar mengawali ketertarikannya terhadap politik lewat apa yang ia pahami mengenai DPRD sebagai tempat suatu kebijakan dirumuskan. Anggapan Ar adalah DPRD merupakan ranah bagi laki-laki sehingga kebijakan-kebijkan yang diterbitkan banyak yang tidak merepresentasikan perempuan, dituturkannya:

"Saya melihat bahwa perempuan perlu terlibat didalamnya, kepentingan perempuan harus diperjuangkan apalagi oleh kita para perempuan, saya melihat cara paling efektif adalah mencalonkan diri menjadi wakil rakyat yang mau tidak mau harus mengikuti proses pencalonan melalui partai, melewati proses pemilu dan masuk ke dunia parlemen".

Politik dianggap Ar sebagai jalan terbaik agar politik memperhatikan kebutuhan perempuan, apalagi Ar seorang perempuan yang juga menginginkan kebutuhan pelayanan negara mengarah pada kaum perempuan. Konstruksi pikir yang mulai mengenali politik sebagai jalan penghapusan terhadap segala jenis diskriminasi terhadap perempuan. Ft memiliki motivasi untuk berpolitik sejak saat ia masih menjadi anak dari sebuah keluarga yang memiliki kecenderungan terhadap dunia politik. Penuturan Ft diungkapkan sebagai berikut:

"Keluarga saya adalah keluarga yang sudah berkecimpung di dunia politik, ayah dan kakak saya adalah pengurus partai dan seorang anggota legislatif, kakek saya pun juga salah seorang pendiri partai politik yang besar. Saya sendiri mulai terjun ke dunia politik mulai dari menjadi istri seorang Polisi di era orde baru yang mendorong saya untuk aktif di politik".
Sosialisasi serta proses belajar lain mengenai lingkungan politik telah akrab ia ketahui sejak masih berstatus sebagai anak di dalam sebuah keluarga. Kemudian pada saat ia dewasa dan berkeluarga jiwa politik mulai semakin terlihat didukung oleh lingkungan yang membuatnya mampu untuk berkiprah di dalam dunia politik.

$\mathrm{Rb}$ selaku ibu rumah tangga pun memiliki motivasi yang ia bahkan tidak sangka:

"Saya dulu seorang rumah tangga biasa, saya dulu gak boleh kerja sama suami. Tapi dulu pas saya masih kuliah saya aktif di Senat gitu mbak, saya basic-nya hukum. Nah waktu itu saya mulai mencoba untuk mencari kegiatan mengisi waktu luang saya, saya meminta izin suami untuk melakukan aktivitas di masyarakat seperti PKK dan Jumantik seperti itu lho mbak. Pada waktu itu saya mencoba mencari aktivitas lain yang dapat mengisi waktu luang. Kebetulan tetangga saya mengajak saya untuk terjun ke dunia politik, saya pun akhirnya masuk"

Aktivitas sosial kemudian menjadi alternatif pilihan bagi $\mathrm{Rb}$ untuk mengisi waktu luang dan hasrat sebagai perempuan aktif yang memang telah ia kantongi sejak menjadi anggota senat mahasiswa. Berawal dari kegiatan PKK di kampung yang telah ia geluti, sarana sosialisasi dirinya dengan masyarakat sekitar rumah dapat dicapai dengan mudah. Keaktifan yang ia tunjukkan di dalam ruang organisasi PKK ini dilihat oleh sebagian masyarakat sekitar rumahnya sebagai sosok yang patut untuk diajak bergabung ke dunia politik. Maka benar saja tujuan mengisi waktu luang itu terwujud karena $\mathrm{Rb}$ terpilih menjadi anggota DPRD Kota Yogyakarta.

An yang kala itu berprofesi sebagai ibu rumah tangga juga menjelaskan bahwa ia mengikuti kegiatan politik karena direkrut oleh tetangganya 
Jurnal Pemikiran Sosiologi Volume 4 No. 2, 2017

Wajah Politik Perempuan: Studi Etnografi Representasi Suara Perempuan dalam Pemilu Legislatif 2014 di Propinsi Daerah Istimewa Yogyakarta (DIY)

Anis Izdiha

yang seorang aktivis partai, sebagaimana penuturannya ini:

"Ya memang saya ikut terjun ke politik oleh sebab tetangga saya, namun pada saat saya mencalonkan diri menjadi calon legislatif, rumah saya mendadak ramai dikunjungi oleh masyarakat. Waktu itu saya mulai berfikir bahwa jika saya tidak serius ya akan percuma saja, akhirnya saya harus terus berusaha saya kira harus total"

An mulai tertarik secara pribadi terhadap politik ketika mendapat respon positif dari masyarakat. Tanggapan positif ini menjadi suatu kebanggaan tersendiri bagi An karena merasa dihargai dan mulai dilihat oleh masyarakat sekitar rumahnya. Daya tarik ulur antara masyarakat dengan anggapan terhadap caleg menciptakan sebuah inisiatif bagi sang caleg untuk tertarik ke dunia politik. Perasaan mendapat 'dukungan' menambah daftar ketertarikan caleg perempuan untuk maju. An sekarang menjabat sebagai Wakil Ketua DPRD Kota Yogyakarta.

\section{Implikasi Kuota Keterwakilan Perempuan dalam Pemilu 2014 di Yogyakarta}

Persoalan pertama mereka adalah bagaimana meyakinkan para pemilih ini bahwa perempuan juga layak untuk menduduki jabatan sebagai wakil rakyat. Surve IFES di tahun 2010 menunjukkan bahwa prosentase pemilih terhadap calon legislatif perempuan hanya 12\%. (Serpe, 2010).

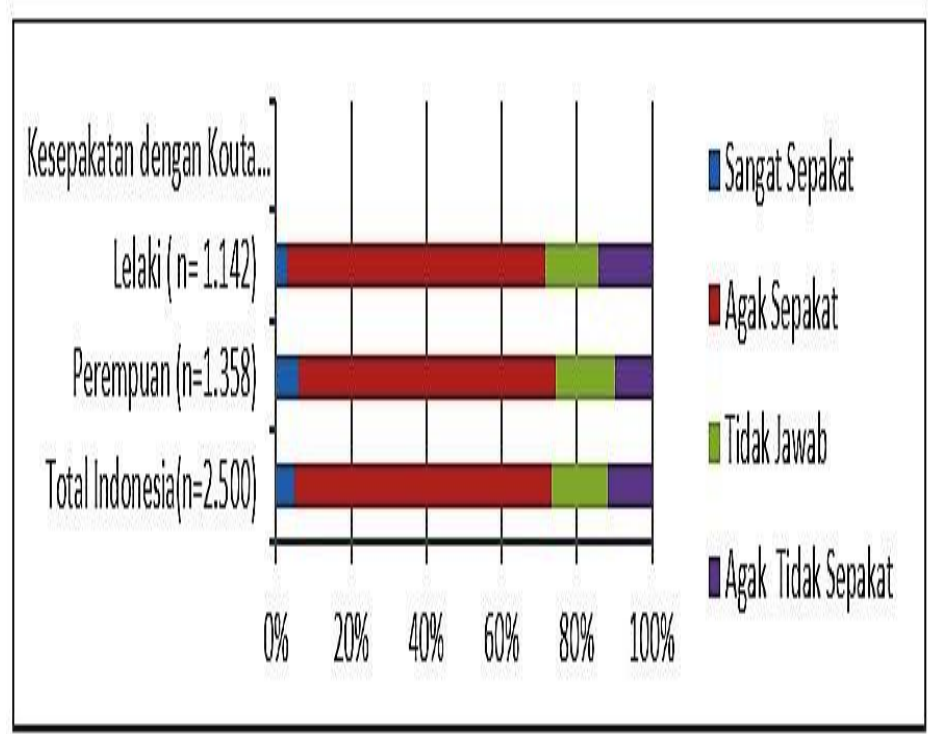

Gambar 02. Prosentase Pemilih terhadap Caleg Perempuan (Sumber : Serpe, 2010)

Kenyataan ini menjadi sebuah patokan pikir awal bagi para caleg perempuan, mereka sadar bahwa caleg perempuan bahkan sejak kemunculannya dimata masyarakat tetap masih dianggap sebagai sosok yang masih 'diragukan'. Asumsi ini kian merajuk menjadi gagasan objektif yang harus 'diterima' oleh para calon legislatif perempuan.

Selain itu, persoalan lain juga muncul terkait pendidikan politik yang belum para caleg perempuan kuasai betul. Lima dari informan saya mengatakan bahwa pendidikan politik yang mereka dapat dari partai politik hampir tidak ada. Nv sebagai salah seorang pengurus harian parpol menuturkan bahwa partai politik tidak memiliki anggaran yang cukup untuk melakukan pendidikan politik bagi setiap kader calegnya. Sadar akan minimnya kapasitas para caleg perempuan akan pengetahuan tentang bagaimana menjalankan proses berpolitik, organisasi perempuan pun 
Jurnal Pemikiran Sosiologi Volume 4 No. 2, 2017

Wajah Politik Perempuan: Studi Etnografi Representasi Suara Perempuan dalam Pemilu Legislatif 2014 di Propinsi Daerah Istimewa Yogyakarta (DIY)

Anis Izdiha

mengambil peran sebagai 'tim suksesi' bagi para caleg perempuan.

Penempatan daerah pilihan serta nomor urut dari calon legislatif 'dimainkan' oleh partai politik. Data yang terkumpul di NARASITA (2014), hanya 6\% calon legislatif perempuan yang menduduki nomor urut 1. Mereka diletakkan pada nomor urut 2 hingga urutan terakhir. Lebih dari pada itu, calon legislatif perempuan diletakkan pada daerah-daerah rawan minim pemilih. Seperti misalnya salah seorang caleg perempuan yang berasal dari daerah kota akan tetapi dipidah ke daerah pemilihan yang ada di Gunungkidul.

Perempuan politik melihat potensi bagi dirinya sebagai 'seorang perempuan'. Identitas sebagai seorang perempuan diasumsikan oleh mereka sebagai awal baik karena jumlah penduduk perempuan diasumsikan memiliki jumlah lebih besar dibandingkan dengan jumlah penduduk lakilaki di DIY. Jumlah pemilih di DIY terdiri dari perempuan $51,53 \%$ dan pemilih laki-laki $48,47 \%$.

\begin{tabular}{|c|c|c|c|c|c|c|c|}
\hline \multirow[t]{2}{*}{ No } & \multirow{2}{*}{$\begin{array}{l}\text { Nama Kabupaten/ } \\
\text { Kota }\end{array}$} & \multirow{2}{*}{$\begin{array}{l}\text { Jumlah } \\
\text { Kecamat } \\
\text { an } \\
\end{array}$} & \multirow{2}{*}{$\begin{array}{l}\text { Jumlah } \\
\text { Desa }\end{array}$} & \multirow{2}{*}{$\begin{array}{l}\text { Jumlah } \\
\text { TPS }\end{array}$} & \multicolumn{3}{|c|}{ Jumlah Pemilih } \\
\hline & & & & & $\mathrm{L}$ & $P$ & $\mathrm{~L}+\mathrm{P}$ \\
\hline 1 & Kulon Progo & 12 & 88 & 987 & 162.529 & $\begin{array}{l}173.36 \\
8\end{array}$ & 335.897 \\
\hline 2 & Bantul & 17 & 75 & 2.293 & 349.136 & $\begin{array}{l}369.82 \\
3\end{array}$ & 718.959 \\
\hline 3 & Gunungkidul & 18 & 144 & 1.898 & 290.133 & $\begin{array}{l}307.45 \\
6 \\
\end{array}$ & 597.587 \\
\hline 4 & Sleman & 17 & 86 & 2.374 & 382.892 & $\begin{array}{l}406.65 \\
8 \\
\end{array}$ & 789.550 \\
\hline 5 & Kota Yogyakarta & 14 & 45 & 802 & 149.235 & $\begin{array}{l}161.04 \\
5 \\
\end{array}$ & 310.280 \\
\hline & JUMLAH & 78 & 438 & 8.354 & $\begin{array}{l}1.333 .92 \\
5 \\
\end{array}$ & $\begin{array}{l}1.418 .3 \\
50 \\
\end{array}$ & 2.752 .275 \\
\hline
\end{tabular}

Tabel 04. Jumlah Pemilih Tetap DIY Pemilu 2014 (Sumber : KPU DIY, 2014).
Data di atas menunjukkan bahwa pemilih perempuan memiliki jumlah lebih besar dibandingkan dengan jumlah pemilih laki-laki, namun jika dilihat secara lebih rinci perbedaannya hanya 3,06\% . Memang perbedaan tersebut dapat dilihat merata pada tiap kabupaten/kota namun selisih jumlah yang tidak banyak ini masih perlu diperhatikan jika kita lebih lanjut berbicara mengenai keberpihakan perempuan. Celaka lagi, asumsi yang timbul dari data jumlah pemilih perempuan masih dianggap sebagai poin plus bagi caleg perempuan.

Strategi kampanye dari empat informan hampir mirip sedang hanya satu yang melakukan perbedaan. $\mathrm{Nv}$ dan $\mathrm{Rb}$ melakukan aktivitas kampanye melalui sosialisasi ke komunitaskomunitas perempuan, seperti PKK, lansia, serta perkumpulan perempuan lain. Ar juga melakukan hal yang sama dengan memaksimalkan kantong struktural dari organisasi keagamaan perempuan yang ia geluti, seperti pernyataannya;

"Strategi kampanye saya memaksimalkan kantong struktural dari ranting-pusat melalui ormas Aisyiyah, juga jaringan-jaringan lain".

Ft sebagai sosok yang sudah incumbent mengupayakan suara melalui mempertahankan konstituennya yang juga dari kalangan segmentasi perkumpulan ibu-ibu. Sedangkan An lebih banyak berkampanye kepada masyarakat luas seperti perkumpulan bapak-bapak, anak muda, hingga ibuibu juga. Strategi lain yang juga dilakukan adalah penguatan jumlah pemilih di dalam keluarga di Jawa khususnya di Yogyakarta, tradisi trah (kumpulan keluarga) masih juga kental dilaksanakan. Kantong pemilih keluarga juga dilihat sebagai peluang bagi 
Jurnal Pemikiran Sosiologi Volume 4 No. 2, 2017

Wajah Politik Perempuan: Studi Etnografi Representasi Suara Perempuan dalam Pemilu Legislatif 2014 di Propinsi Daerah Istimewa Yogyakarta (DIY)

Anis Izdiha

caleg perempuan untuk mendulang suara. Dari paparan di atas, dapat kita ketahui bahwa simpul dari subyek pemilih yang dituju oleh para calon legislatif perempuan ini adalah 'perempuan' dan keluarga serta strategi pendekatan lebih banyak melalui komunitas perempuan.

Jargon menuntut kesetaraan menjadi mitos yang berkembang baik di kalangan perempuan sebagai bagian dari alam mimpi. Ia berkembang menjadi kecenderungan dan ekspresi dari perempuan. Ekspresi ini kemudian berubah menjadi satu bahasa universal politik perempuan. ${ }^{2}$ Perempuan politik dari kalangan manapun dapat mengatasnamakan diri mereka di atas panggung politik atas nama kesetaraan gender. Pada tataran ini seolah setiap perempuan politik memiliki sikap politik yang sama di hadapan publik.

Strategi komunikasi politik perempuan kemudian menemui keakuan hanya pada lingkup-lingkup tertentu. Arah komunikasi politik perempuan berbasis pada primodialisme menuju pada kolektivisme diantara para caleg perempuan. Semangat kolektivisme ini disebut sebagai Feminisme kekuatan oleh Wolf (1997), perempuan menentukan langkah-langkah praktis raksasa mewujudkan toleransi, mengidentifikasi diri satu sama lain terutama melalui keperempuan yang memiliki sisi kesenangan dan kekuatan yang digenggam bersama-sama, bukan untuk menanggung penderitaan bersama akan tetapi

\footnotetext{
2 Pada awalnya bahasa politik merupakan isi pesan (content: message) dari suatu proses komunikasi yang melibatkan komunikator politikng. Bahasa politik dapat diartikan merupakan asil dari proses komunikasi politik. Komunikasi politik pada dasarnya adalah komunikasi yang diupayakan untuk mencapai tujuan-tujuan politik tertentu (McNair,1995,Pwito,2009). Bahasa politik ini
}

untuk kemajuan bersama. Berkembangnya isu ini menciptakan sebuah komunitas bayang dengan nama “Gendermania"(Nugroho, 2011).

Dana kampanye juga bagian pokok penting yang harus diperhatikan oleh para caleg perempuan. Godaan serta rayuan masyarakat yang seringkali datang kepada mereka sulit untuk diterpa hanya dengan ujaran atau omongan belaka. Bagi mereka yang sudah meniti karir sebelum melakukan pencalonan seperti Ar dan Ft, dana kampanye mereka kumpulkan dari gaji yang mereka dapatkan dari bekerja. Sedangkan bagi mereka yang berprofesi sebagai ibu rumah tangga maupun pekerjaan swasta lain seperti An, Rb, dan Nv, dana kampanye mereka dapatkan dari sosok 'suami' mereka. Berapapun dari uang yang diberikan suami kepada mereka, dana itulah yang akan menjadi modal utama 'nyaleg', sebagaimana pernyataan salah satu informan, $\mathrm{Rb}$ sebagai berikut:

"Modal saya gak banyak bahkan tidak lebih dari 10 juta. Suami kan bekerja di luar kota, dan saya bisa melakukan apapun yang dikatakan suami, suami bilang uang segitu ya sepinter-pinter saya untuk mengalokasikannya."

Penggunaan dana kampanye diungkap oleh lima informan untuk keperluan mencetak stiker, membayar saksi TPS (Tempat Pemungutan Suara), spanduk, dan alat peraga kampanye lainnya. Dana kampanye juga tidak jarang digunakan untuk ngopeni konstituen atau menjaga agar kantong

kemudian dipropagandakan sebagai kontrol akan presepsi masyarakat sekaligus alat pengendalian tentang apa yang harus dipikirkan masyarakat tentang perempuan politik, Lihat Ibrahim, Idi Subandy dan Deddy Djamaluddin Malik (eds). 1997. Hegemoni Budaya. Yogyakarta: Yayasan Bentang Budaya, hlm 45 
Jurnal Pemikiran Sosiologi Volume 4 No. 2, 2017

Wajah Politik Perempuan: Studi Etnografi Representasi Suara Perempuan dalam Pemilu Legislatif 2014 di Propinsi Daerah Istimewa Yogyakarta (DIY)

Anis Izdiha

pemilih di daerah pemilihannya bersimpati kepada mereka. Hal ini diungkapkan oleh informan $\mathrm{Ar}$ sebagai berikut:

"Dana kampanye saya gunakan untuk timses segala macem, kalau proposal-proposal masyarakat saya mengukur diri kalau bisa saya membantu mereka ya saya bantu, atau menghubungkan mereka dengan pemerintah setempat. Saya memang terkadang memberikan uang kepada organisasi atau lembaga khususnya perempuan, saya ngasihnya bentuknya ke kas bukan personal maupun massal. Ya tapi gitu mbak tetap tidak terpilih itu padahal sudah di kantong organisasi perempuan mereka masih belum respek"

Ar menunjukkan pada kita mengenai resiko yang mungkin saja diterima oleh sebagian caleg saat berkampanye yaitu jumlah atau seluruh upaya yang dilakukan tidaklah akan selalu sama dengan hasil yang akan di dapat. Kantong pemilih perempuan tidak mesti mau untuk menunjukkan simpati mereka terhadap caleg perempuan.

Organisasi Perempuan memiliki peran penting di dalam melakukan akomodasi politik perempuan. Upaya mempersatukan para caleg perempuan pun dilakukan oleh NARASITA melalui Forum Komunikasi Perempuan Politik DIY. Beberapa aksi damai telah dilakukan dengan mengumandangkan keberpihakan terhadap caleg perempuan. Upaya publikasi dan pelebaran ke ranah media diwujudkan pada kolom Jendela koran Minggu Pagi. Gerakan mewujudkan motto bersama yakni BERSIAP (Bersih, Efisien, Aspiratif) di dalam Forum Perempuan Calon Anggota Legislatif DPRD Kabupaten/Kota, DPRD DIY, DPR RI, DPD RI pada tanggal 8 Januari 2014. Beberapa poin yang disampaikan dalam forum tersebut adalah sebagai berikut:
1) Turut menciptakan sistem politik yang Bersih, Efisien, dan Aspiratif.

2) Perempuan Caleg DIY berkomitmen untuk menciptakan Pemilu yang anti money politics, santun, beretika dan berbudaya.

3) Perempuan Caleg DIY berkomitmen untuk taat pada aturan dan undang-undang yang berlaku, mengembangkan jaringan di masyarakat sebagai pendukung dan bermitra demi tujuan kesejahteraan rakyat.

4) Perempuan Caleg DIY juga memiliki komitmen untuk tanggap dan responsive terhadap persoalan masyarakat.

Konferensi pers yang dilakukan oleh 21 NGO di Lembaga Bantuan Hukum (LBH). Ada beberapa wartawan dan juga masyarakat umum yang hadir. Acara dimulai pada pukul 11.00-12.00 WIB. Beberapa caleg yang tidak direkomendasikan untuk dipilih diserahkan kepada publik untuk dikaji bersama. Hal yang juga patut untuk kita apresiasi bersama bahwa TIDAK ADA caleg perempuan yang terindikasi masuk dalam daftar caleg yang tidak direkomendasi untuk dipilih yang berarti tidak ada alasan yang jelek untuk tidak memilih caleg perempuan sebagai wakil rakyat.

Upaya lain yang tak kalah penting adalah dengan diselelnggarakannya Kursus Perempuan Parlemen (KPP). Kursus ini diselenggarakan oleh NARASITA bekerjasama dengan BPPM DIY untuk menjaring para calon legislatif perempuan untuk kemudian diberikan materi-materi pokok di dalam melihat proses berpolitik praktis. Kegiatan ini dilaksanakan dalam sebulan sekali. Keterangan yang penulis dapat dari Kepala Sekolah, sebutan yang akrab menyapa saat kelas kursus ini berlangsung ada 
Jurnal Pemikiran Sosiologi Volume 4 No. 2, 2017

Wajah Politik Perempuan: Studi Etnografi Representasi Suara Perempuan dalam Pemilu Legislatif 2014 di Propinsi Daerah Istimewa Yogyakarta (DIY)

Anis Izdiha

setidaknya 10 materi yang diberikan kepada calon legislatif perempuan, diantaranya adalah Konsep dan Teori Gender, Komunikasi Politik, Kepemimpinan Perempuan, Kiprah Perempuan dalam Politik, Prioritas Sektoral, Perempuan dan MDG's, Perundang-Undangan, Manajemen Konstituen, Anggaran Responsif Gender, Pemilu , Pendidikan Perempuan dan Partai Politik, Strategi Politik dan Skoring Penempatan, Manajemen Perubahan, dan Fungsi Cara Kerja Legislator.

Komponen lain yang juga perlu diperhatikan adalah 'tim sukses'. $\mathrm{Rb}$ mengungkapkan bahwa dirinya mengangkat tiga tim sukses yang semua berasal dari kalangan perempuan, "tidak banyak yang saya janjikan kepada mereka waktu itu karena saya tidak punya uang, namun setelah saya jadi nanti saya akan belikan kalian motor satu-satu", begitu ungkap $\mathrm{Rb}$. $\mathrm{Nv}$ dan $\mathrm{Rb}$ membentuk tim sukses sendiri dengan memanfaatkan dana bansos partai untuk materi yang bisa ia salurkan kepada masyarakat. Ar dan An juga membentuk tim sukses sendiri dengan dana pribadi yang ia keluarkan. Perempuan politik telah mampu untuk membentuk tim sukses mandiri meskipun jumlah dan kualitas dari tim sukses tidak begitu dipermasalahkan.

Gerakan perempuan yang diusung oleh Perkumpulan NARASITA pada pemilu 2014 menjadi 'mediasi' serta ruang 'konsolidasi' untuk melancarkan gerakan-gerakan politik perempuan. Langkah-langkah serta upaya membangun opini publik mengenai calon legislatif perempuan dilakukan melalui gerakan perempuan. Para calon legislatif dikumpulkan untuk menetapkan satu tujuan bersama, satu kesepakatan bersama terkait 'sikap' seorang perempuan politik. Pendidikan politik serta pembekalan pra pemilu diberikan melalui perantara Perkumpulan NARASITA. Gerakan perempuan membantu proses pembentukan agenda-agenda politik perempuan. Oleh karenanya organisasi perempuan memiliki peran 'mendorong' serta 'membantu' pemetaan politik perempuan.

Beberapa aksi damai telah dilakukan dengan mengumandangkan keberpihakan terhadap caleg perempuan. Upaya publikasi dan pelebaran ke ranah media diwujudkan pada kolom Jendela koran Minggu Pagi. Para caleg perempuan juga mewujudkan motto bersama yakni BERSIAP (Bersih, Efisien,Aspiratif) di dalam Forum Perempuan Calon Anggota Legislatif DPRD Kabupaten/Kota, DPRD DIY, DPR RI, DPD RI pada tanggal 8 Januari 2014. FORKOMM menjadi agen penting di dalam Gerakan 'Pilih Caleg Perempuan' diselenggarakan di DIY pada tanggal 23 Februari 2014 di Bundaran HI Jakarta bersama dengan acara yang diselenggarakan oleh Kementerian Pemberdayaan Perempuan dan Perlindungan Anak di Yogyakarta.

Caleg perempuan bersepakat bersama-sama untuk mewujudkan pemilu damai yang jujur dan adil pada penandatanganan 'Pakta Integritas Perempuan Calon Anggota DPR, DPD, dan DPRD dari Daerah Istimewa Yogyakarta Pemilu 2014' yang diselenggarakan di Gedung DPRD DIY tanggal 28 Februari 2014. Pakta Integritas ini berupa pernyataan janji dihadapan publik yang diwakili oleh Perempuan Kepala/Wakil Kepala Daerah Kabupaten/Kota se-DIY, KPUD se-DIY, Bawaslu dan Panwaslu se-DIY, perwakilan LSM, perwakilan Perguruan Tinggi, perwakilan ormas (Organisasi 
Jurnal Pemikiran Sosiologi Volume 4 No. 2, 2017

Wajah Politik Perempuan: Studi Etnografi Representasi Suara Perempuan dalam Pemilu Legislatif 2014 di Propinsi Daerah Istimewa Yogyakarta (DIY)

Anis Izdiha

Masyarakat) perempuan dan pemilih pemula di DIY dan ditandatangani oleh masing-masing calon legislatif perempuan yang membuat janji.

Strategi di atas diasumsikan oleh kesepakatan para caleg perempuan sebagai taktik untuk menggugah opini masyarakat. Akan tetapi pada saat hari $\mathrm{H}$ pemungutan suara. Ar, Nv, dan Ft menyatakan bahwa alasan terbesar kekalahan mereka adalah praktik money politic atau 'serangan dhuha' yang dilancarkan oleh calon lain. Ft menuturkan, sebagai berikut:

"Pada saat hari H lepas oleh karena uang 100 an yang disebar oleh lawan main . Saya sendiri sebenarnya kalah 150an suara dengan caleg lain, lah itu lah mbaak sekarang itu golek suara itu ya tuku, orang konstituen yang saya openi itu lupa, lupa semua mereka padahal saya sudah bertaruh mempertaruhkan jabatan tapi tetap saja mereka itu lupa, beliau mencontohkan teman se partainya gagal padahal sudah bertahun-tahun ngopeni konstituen tidak lain ya dicolong konco partai dewe"

Money politics masih menjadi ancaman besar dari para calon legislatif perempuan. Praktik ini dianggap telah 'melukai' serangkain upaya yang telah dilakukan seorang caleg untuk bekerja membangun di masyarakat setidaknya pada saat kampanye. Karakter pemilih yang diasumsikan 'lupa karena uang' juga menjadi tolor ukur ketidakberhasilan seorang caleg. Money politic merubah orientasi pemilih dengan begitu cepat dan mengena. Ft menyayangkan karena pemilu dengan money politic sama saja dengan ngopeni duit recehan.

Praktik-praktik perempuan di dalam kampanye pemilu 2014 ini dapat kita lihat dari uraian di atas. Ruang kampanye menjadi lahan mandiri bagi para caleg perempuan untuk mendulang suara tanpa bantuan dari partai politik. Keterlibatan perempuan di dalam kampanye masih ada pada tataran melaksanakan prosedur yang diamanatkan dalam sistem yang tercermin dalam aturan-aturan yang ditetapkan oleh sistem pemilihan umum. Meski begitu, berbagai taktik dan strategi peempuan di dalam pemilu menjadi gambaran penting terkait bagaimana perempuan merespon kebijakan ini dengan alur pikir dan nalar. Pertimbangan ekonomi, moral, dan rasional juga diikutsertakan perempuan di dalam mengambil langkah.

\section{E. Suara Perempuan 'Tidak Diakui' di dalam Parlemen}

Kata 'terpilih' menjadi gerbang utama bagi seorang caleg untuk masuk ke dunia parlemen. Pemenuhan syarat kelengkapan administrasi anggota dewan dilaksanakan serta dilengkapi oleh sumpah jabatan sebelum mereka resmi menyandang status Anggota Dewan Perwakilan Rakyat Daerah. Keterlibatan perempuan di dalam parlemen mengisyaratkan satu hal yakni eksistensi di ruang publik, baik karena kesetaraan hak maupun pengakuan kualitas (Santoso dan Joash, 2012). Meski begitu, Saat seorang calon legislatif perempuan ditetapkan sebagai anggota dari DPRD, ada dua pihak yang masih membelenggunya yaitu partai politik dan organisasi perempuan.

Partai politik memainkan perannya sebagai pengusung kader atau sebagai kendaraan. An, Rb, dan Ft menyatakan bahwa biaya terbesar dalam nyaleg itu sebenarnya adalah uang pasok kepada partai setelah mereka terpilih. Mengapa demikian? Tentu saja dapat dijelaskan melalui posisi partai 
Jurnal Pemikiran Sosiologi Volume 4 No. 2, 2017

Wajah Politik Perempuan: Studi Etnografi Representasi Suara Perempuan dalam Pemilu Legislatif 2014 di Propinsi Daerah Istimewa Yogyakarta (DIY)

Anis Izdiha

politik saat mereka sudah memasuki gerbang parlemen. Partai politik memiliki kewenangan untuk 'menentukan' dimana para anggota dewan ini duduk. Posisi yang akan didapat di dalam struktur dewan, apakah di komisi A, B, C, atau D ditentukan oleh partai politik. Seluruh partai politik yang hadir di dalam kepengurusan tersebut 'berunding' dan menentukan posisi bagi masing-masing kader mereka yang terpilih. Setiap kader dari satu partai tertentu akan disebut 'fraksi' atau perwakilan suara partai di dalam tubuh parlemen. Suara partai politik hadir melalui kader-kader yang masuk ke dunia parlemen.

$\mathrm{Rb}$ menjabat sebagai Wakil Ketua II DPRD Kota Yogyakarta oleh karena dirinya diamanatkan oleh partai untuk duduk di jabatan tersebut, "saya duduk di WK II ditunjuk oleh partai karena saya struktural ya, bendahara satu partai saya". Sedangkan An sebagai aleg incumbent dari partainya duduk pada jabatan fraksi partai atau setaraf posisi anggota saja. An masuk ke komisi C atau komisi kebijakan infrastruktur oleh arahan partainya. Ft juga duduk di komisi D atau komisi pendidikan dan pelatihan juga atas arahan partai politik. Masing-masing anggota telah tercampur bersama dengan anggota legislatif partai lain dalam komisi entah A, B, C, dan D, namun pada saat melakukan wawancara kepada para anggota legislatif ini di kantor legislatif Kota Yogyakarta, saya melihat banyak ruang-ruang dengan lambang partai di depan pintu ruang. Jika ada 10 partai dengan kader mereka yang terpilih, maka ada 10 ruang yang dinamakan 'ruang fraksi', begitu penuturan dari salah seorang petugas informasi kantor DPRD Kota Yogyakarta. Partai memiliki suara kuat di dalam parlemen, bahkan tidak heran jika parlemen dikatakan oleh para pengamat politik sebagai 'penjelmaan' dari partaipartai politik yang hadir.

Implikasi nyata yang mungkin terlihat adalah keputusan-keputusan yang diambil oleh para anggota parlemen tidak dapat dipisahkan dari suara partai. Seorang anggota legislatif tidak dapat menentukan kebijakannya sendiri tanpa arahan partai politik. Keputusan dibuat dan dirundingkan bersama oleh sekawan partai atas nama 'fraksi'. Setelah masing-masing fraksi memiliki kesepakatan mereka masing-masing, akan diadakanlah Sidang Paripurna untuk membahas kesepakatan lintas fraksi, begitu paparan dari Ft terkait proses pengambilan keputusan.

Disisi lain, seperti yang telah dibahas pada sebelumnya perempuan anggota legislatif ini memiliki 'tanggungjawab moral' yang 'dititipkan' oleh para aktivis perempuan untuk mengentaskan persoalan perempuan melalui kebijakan-kebijakan yang akan mereka upayakan untuk disahkan. Pembentukan Kaukus Perempuan Parlemen (KPP) juga diwujudkan untuk menjadi wadah konsolidasi bagi seluruh anggota parlemen perempuan untuk mendesakkan dan menerbitkan Perda-Perda yang berkaitan dengan kepentingan perempuan. Akan tetapi, $\mathrm{Rb}, \mathrm{An}$, dan $\mathrm{Ft}$ bersepakat dalam satu pendapat bahwa KPP hanya menjadi ajang-ajang kumpul saja, mereka melakukan pertemuan rutin dengan acara arisan dalam balutan KPP, sebagaimana yang diungkapkan oleh Ft sebagai berikut:

"Pendapat saya akan hadirnya Kaukus Perempuan Parlemen juga biasa-biasa saja ya, mung kumpulkumpul tok, sebenarnya kan fungsinya adalah bagaimana kita semua pejabat perempuan yang 
Jurnal Pemikiran Sosiologi Volume 4 No. 2, 2017

Wajah Politik Perempuan: Studi Etnografi Representasi Suara Perempuan dalam Pemilu Legislatif 2014 di Propinsi Daerah Istimewa Yogyakarta (DIY)

Anis Izdiha

duduk menyamakan satu visi tapi ya gimana KPP ini "tidak punya gigi". Saya dan teman-teman anggota legislative perempuan sering menitipkanya lewat fraksi karena suaranya ada"

Lebih lanjut, Ft menjelaskan mengenai kiprahnya di dalam mencoba meloloskan suatu kebijakan yang menurutnya akan menjadi jalan keluar beberapa persoalan perempuan.

"Dulu saya bersama 4 anggota tim anggota DPRD perempuan membuat perda inisiatif Kota layak Anak, itu adalah ide saya, dari 5 orang itu sebenarnya satu meninggal dunia, dan yang satu tidak berkontribusi sama sekali. Harapan saya waktu itu adalah bila mana layak anak itu ya lingkungan juga akan menjadi ramah, dia akan menjadi Perda induk karena jika Perda ini hadir maka akan lahir pula Perda no rokok, Perda ruang laktasi di tempat umum, dan seterusnya. Tapi seusai saya selesai menjabat tampaknya ini hanya menjadi gagasan saja, tinggal draft saja, tapi ndak ada yng melanjutkan. Padahal ada satu caleg yang satu partai dengan saya namun dia tidak melanjutkan"

Usulan perempuan hanya menjadi usulan, begitu tutur Ft oleh sebab betapapun dirinya bersama empat kawannya bersuara di dalam siding paripurna, mereka tetap tidak akan mendapatkan lebih dari anggukan atau sekedar kata 'ide bagus'. Kebulatan dari persatuan perempuan yang ingin diwujudkan dalam parlemen pun rumpang oleh sebab mereka pun harus bersuara menurut suara dari partai mereka. Saat satu aleg perempuan bersuara dan disetujui oleh fraksi partainya, aleg perempuan lain bisa jadi tidak dapat mengatakan untuk setuju jika partainya tidak menyatakan setuju.

Lalu apakah kreativitas dari masing-masing aleg menjadi 'bungkam'? teryata tidak juga, partai politik memberikan ruang bagi para kader aleg-nya untuk membuat program-program yang dicetuskan secara mandiri. Para kader anggota legislatif diperbolehkan mengambil tema apapun untuk dijadikan program. Catatan penting yang mesti dilihat adalah ruang diberikan dalam wujud 'program' bukan pada tataran 'keputusan' fraksi.

$\mathrm{Ft}, \mathrm{An}$, dan $\mathrm{Rb}$ menceritakan bagaimana mereka bekerja sebagai seorang anggota legislatif. Ft yang duduk di komisi D memfokuskan pada program pelatihan ketrampilan bagi perempuan, menuturkan sebagai berikut:

"Saya dulu ada di komisi D, kegiatan yang saya lakukan adalah membuat kegiatan pemberdayaan, kami bekerjasama degan Dinas Sosial untuk memberikan modal usaha serta berbagai pelatihan bagi kelompok-kelompok perempuan dampingan kami, ada kelompok pembatik, membordir, menyulam, dan lain sebagainya, ya ada peserta 1-2 laki-laki tapi kami fokus pada bahasan perempuan."

Begitu pula dengan $\mathrm{Rb}$, program-program yang digagas olehnya adalah program yang berkaitan dengan perempuan dan anak. Bahkan $\mathrm{Rb}$ menjelaskan bahwa:

"Saya ini seringkali didatangi oleh ibu-ibu Lurah dari masing-masing wilayah karena $R b$ sering sekali meloloskan program yang berkaitan dengan perempuan dan anak. Program-program saya berkaitan dengan program anak-anak dan perempuan mbaak, nek hal-hal fisik itu umumnya sudah diurusi oleh para caleg laki-laki. Contohnya saya pernah supplay acara kegiatan PAUD, Sekolah Bunda, Dhuafa dan seterusnya. Kemudian ada cerita bahwa Ibu Lurah tetangga sebelah itu minta dana ya saya akhirnya mengupayakan dan akhirnya berhasil. Nominalnya memang tak seberapa tapi yang jelas kita membantu."

Cerita lain datang dari An sebagai Ketua Komisi C, dalam pandangannya perempuan juga memiliki tubuh yang segar tanpa gangguan untuk apa dibuatkan jalan khusus perempuan, itu nanti akan 
Jurnal Pemikiran Sosiologi Volume 4 No. 2, 2017

Wajah Politik Perempuan: Studi Etnografi Representasi Suara Perempuan dalam Pemilu Legislatif 2014 di Propinsi Daerah Istimewa Yogyakarta (DIY)

Anis Izdiha

menjadikan perempuan terlihat lemah. Beliau juga menambahkan bahwa jika memang penerima manfaat adalah tuna wisma, tuna wicara, tuna rungu itu jelas diperbolehkan dan amat sangat membantu mereka, perempuan memiliki kekuatan tersendiri di dalam mewujudkan ide-ide-nya. An menuturkan pengalamannya sebagai berikut:

"Saya sekarang duduk di Komisi C sebagai ketua, komisi ini membidangi tentang infrastruktur, kalau ditanya program-program saya berkaitan dengan perempuan itu juga tapi masak saya harus membuatkan juga jalan khusus wanita, atau barangkali tangga khusus wanita kan nggak ya mbak, lucu malahan, saya kok merasanya malah perempuan ini dianggap lemah begitu, kalau difabel dan lansia kan memang mereka membutuhkan perhatian khusus berkaitan sarana fisik tubuh mereka lah kalau perempuan sehat dan bugar juga harus dibangunkan infrastruktur yang khusus perempuan, bagaimana itu . Perda yang pernah saya garap diantaranya itu Perda KTS (Kawasan Tanpa Rokok), dulu juga ikut menggagas Kota Layak Anak."

An ini menjadi sosok satu contoh sisi lain dari perempuan politik yang tidak memiliki alasan cukup kuat dalam mewujudkan kebijakan infrastruktur khusus bagi perempuan. Akan tetapi arah orientasi tetap pada pembuatan kawasan yang ramah terhadap perempuan, anak, serta kelompok rentan lainnya. An berpendapat bukan infrastruktur khusus dimaknai sebagai bentuk fisik namun bagaimana pemetaan fungsi dari infrastruktur yang mesti diperhatikan.

Perempuan di parlemen harus baik di mata partai dan organisasi perempuan (publik). Peran ganda yang kini menjadi alasan penting nan perlu diperhatikan seorang aleg perempuan untuk meraih kesuksesan atau bahkan menjadi bukti nyata hasil kerja mereka. Bukti kerja inilah yang nantinya akan menjadi daya tarik apakah ke depan jika mereka mencalonkan diri sebagai calon legislatif pada periode setelahnya. Ada banyak calon legislatif incumbent yang gagal oleh karena tidak mampu menjalankan dua peran di atas yang berarti bukti kerja mereka bisa 'tidak diakui'.

\section{F. Kesimpulan}

Kebijakan kuota affirmative action direspon perempuan dengan baik, terbukti oleh adanya data kenaikan jumlah partisipasi politik di DIY pada Pemilu 2014 di tiga kabupaten DIY. Akan tetapi keterlibatan perempuan di dalam politik masih sebatas merespon adanya sistem, masuk ke partai politik oleh alasan kuat kebijakan kuota, melakukan kampanye baik dengan strategi individu maupun strategi kolektif, dan masuk ke dunia parlemen tanpa memiliki 'suara' kuat.

Orientasi perilaku politik perempuan DIY masih kuat dipengaruhi oleh padangan budaya dan agama yang mereka pahami. Sikap cenderung menghindari konflik pada saat kampanye dan pasrah menerima hasil kekalahan dengan legowo menjadi salah satu cermin sikap politik perempuan yang masih kuat dipengaruhi budaya. Sikap menyerahkan segala hasil dan apa yang mereka terima pada saat melakukan aktivitas politik baik serta buruk kepada Tuhan menunjukkan bahwa politik menjadi bagian dari ekspresi beragama bagi seorang perempuan politik. 
Jurnal Pemikiran Sosiologi Volume 4 No. 2, 2017

Wajah Politik Perempuan: Studi Etnografi Representasi Suara Perempuan dalam Pemilu Legislatif 2014 di Propinsi Daerah Istimewa Yogyakarta (DIY)

Anis Izdiha

\section{Daftar Pustaka}

Adelina, Shelly. 2008. Perempuan Ayo Berpolitik, Jadilah Pemimpin: Sebuah Cerita Bergambar. Jakarta : Program Studi Kajian Wanita Universitas Indonesia, TIFA Foundation

Ahimsa-Putra, Heddy Shri. 2007. Paradigma, Epistemologi, dan Etnografi dalam Antropologi. Makalah disampaikan dalam seminar di UNAIR Surabaya pada bulan Mei

Cantor, Dorothy dan Toni Bernay. 1992. Women in Power: Kiprah Wanita Dalam Dunia Politik. Jakarta : PT Gramedia Pustaka

Craske, Nikki. 1999. Women \& Politics in America Latin. United States : Rutgers University Press

Davies, Charlotte Aull. 1999. Reflexive Ethnography, A guide to Researching Selves and Others. London: Routledge

Gamble, Sarah. 2010. Feminisme dan Post feminisme. Yogyakarta : Jala Sutra

Handayani, Christina dan Ardhian Novianto. 2004. Kuasa Wanita Jawa. Yogyakarta : LKIS Press

Ibrahim, Idi Subandy dan Deddy Djamaluddin Malik (eds). 1997. Hegemoni Budaya. Yogyakarta : Yayasan Bentang Budaya

Klingemann, Hans-Dieter, dkk Sigit Jatmika(tej). 2000. Partai, Kebijakan dan Demokrasi. Yogyakarta : Pustaka Pelajar

Koentjaraningrat. 2009. Pengantar Ilmu Antropologi. Jakarta : Rineka Citra

Nugroho, Riant. 2011. Gender dan Strategi Pengarusutamaannya di Indonesia. Yogyakarta : Pustaka Pelajar

Pamungkas, Sigit. 2010. Pemilu, Perilaku Pemilih dan Kepartaian. Yogyakarta: Institute For Democracy and Welfarism

Perdana, Aditya, dkk. 2013. Panduan Calon Legislatif Perempuan untuk Pemilu 2004. Jakarta : Puskapol UI

Santoso, Purwo dan Joash Tapiheru. 2012. Dilema Kesetaraan Gender : Refleksi dan Respon Praksis. Yogyakarta: Center for Politic And Government (PolGov) Fisipol UGM Press

Saptari, Ratna dan Brigitte M. Holzner. 1997. Perempuan, Kerja dan Perubahan Sosial: Sebuah Pengantar Studi Perempuan. Jakarta : Pustaka Utama Grafiti

Serpe, Lauren, dkk. 2010. Survei Pemilu 2010. Washington,D.C : IFES Press

Spradley, James. 1997. Metode Etnografi. Yogyakarta: Tiara Wacana.
Surbakti, Ramlan. 2007. Memahami Ilmu Politik. Jakarta : PT Grasindo

Sastroatmodjo, Sudijono. 1995. Perilaku Politik. Semarang : IKIP Semarang Press

UNDP. 2003. Partisipasi Politik Perempuan dan Tata Pemerintahan Yang Baik Tantangan Abad 21 terjemahan Pusat Telaah dan Informasi Regional. Jakarta :PATTIRO Press

Utami, Tari Siwi. 2001. Perempuan Politik di Parlemen: Sebuah Sketsa Perjuangan dan Pemberdayaan 1999-2001.Yogyakarta : Gama Media

Wolf, Naomi. 1997. Gegar Gender, Kekuasaan Perempuan Menjelang Abad 21. Yogyakarta: Pustaka Semesta Press

\section{$\underline{\text { Sumber-sumber lain (Leaflet dan Dokumen) }}$}

Profil Organisasi Forum Komunikasi Perempuan Politik DIY

Profil Organisasi NARASITA

Anggaran Dasar dan Aggaran Rumah Tangga Koalisi Perempuan Indonesia untuk Keadilan dan Demokrasi (Untuk Kalangan Sendiri) 